Research article

Open Access

\title{
CYP17 gene polymorphism in relation to breast cancer risk: a case-control study
}

\author{
Kristjana Einarsdóttir ${ }^{1,2}$, Tove Rylander-Rudqvist ${ }^{3}$, Keith Humphreys ${ }^{1}$, Susanne Ahlberg ${ }^{4}$, \\ Gudrun Jonasdottir ${ }^{1}$, Elisabete Weiderpass ${ }^{1,5}$, Kee Seng Chia ${ }^{6}$, Magnus Ingelman-Sundberg ${ }^{4}$, \\ Ingemar Persson ${ }^{1,7}$, Jianjun Liu² ${ }^{2}$ Per Hall1 and Sara Wedrén ${ }^{1,2,6}$
}

\author{
1Department of Medical Epidemiology and Biostatistics, Karolinska Institutet, Stockholm, Sweden \\ 2Population Genetics, Genome Institute of Singapore, Singapore \\ ${ }^{3}$ Division of Nutritional Epidemiology, Institute of Environmental Medicine, Karolinska Institutet, Stockholm, Sweden \\ ${ }^{4}$ Division of Molecular Toxicology, Institute of Environmental Medicine, Karolinska Institutet, Stockholm, Sweden \\ ${ }^{5}$ Cancer Registry of Norway, Montebello, Oslo, Norway \\ ${ }^{6}$ Centre for Molecular Epidemiology, Department of Community, Occupational and Family Medicine, National University of Singapore, Singapore \\ ${ }^{7}$ Swedish Medical Products Agency, Uppsala, Sweden
}

Corresponding author: Kristjana Einarsdóttir, Kristjana.Einarsdottir@meb.ki.se

Received: 25 May 2005 Revisions requested: 8 Jul 2005 Revisions received: 15 Aug 2005 Accepted: 18 Aug 2005 Published: 14 Sep 2005

Breast Cancer Research 2005, 7:R890-R896 (DOI 10.1186/bcr1319)

See related Commentary: http://breast-cancer-research.com/content/7/6/238

This article is online at: http://breast-cancer-research.com/content/7/6/R890

(c) 2005 Einarsdóttir et al.; licensee BioMed Central Ltd.

This is an Open Access article distributed under the terms of the Creative Commons Attribution License (http://creativecommons.org/licenses/by/

2.0), which permits unrestricted use, distribution, and reproduction in any medium, provided the original work is properly cited.

\section{Abstract}

Introduction The c.1-34T>C 5' promoter region polymorphism in cytochrome P450c17 (CYP17), a key enzyme in the biosynthesis of estrogen, has been associated with breast cancer risk, but most previous studies have been relatively small.

Methods We genotyped 1,544 incident cases of primary breast cancer and 1,502 population controls, all postmenopausal Swedish women, for the CYP17 c.1-34T>C polymorphism and calculated odds ratios (ORs) and 95\% confidence intervals (Cls) from logistic regression models.

Results No overall association was found between CYP17 c. 1 $34 \mathrm{~T}>\mathrm{C}$ and breast cancer risk, OR $1.0(95 \% \mathrm{Cl} 0.8-1.3)$ for the
A2/A2 (CC) carriers compared to the A1/A1 (TT) carriers, regardless of histopathology. We detected an interaction between CYP17 c.1-34T $>C$ and age at menarche $(P=0.026)$ but regarded that as a chance finding as no dose-response pattern was evident. Other breast cancer risk factors, including menopausal hormone use and diabetes mellitus, did not modify the overall results.

Conclusion It is unlikely that CYP17 c. $1-34 \mathrm{~T}>\mathrm{C}$ has a role in breast cancer etiology, overall or in combination with established non-genetic breast cancer risk factors.

\section{Introduction}

Estrogen is a central factor in the etiology of breast cancer [1]. One of the key enzymes in the synthesis of sex hormones, such as estrogens and androgens, is cytochrome P450c17 (CYP17). CYP17 catalyses the $17 \alpha$-hydroxylation of pregnenolone and progesterone, and these intermediates are then converted to dehydroepiandosterone and androstenedione by the 17,20-lyase activity of the enzyme $[2,3]$.

A single $\mathrm{T}$ ( $\mathrm{A} 1$ allele) to $\mathrm{C}$ (A2 allele) base change in the $5^{\prime}$ promoter region of CYP17 (c.1-34T $>\mathrm{C}$ ) has been suggested to create an additional binding site for the transcription factor Sp1 [4]. This could theoretically lead to increased levels of the enzyme, but use of the extra binding site has not been confirmed experimentally [5]. Three groups have reported an association of the A2 allele with increased breast cancer risk [6-8] but others have failed to replicate those findings $[5,9$ 21]. A recent meta-analysis of 15 case-control studies did not find any overall association [22] but this analysis was criticized by Feigelson and colleagues [23], who found a borderline significant association between the CYP17 polymorphism and advanced breast cancer.

$\overline{\mathrm{Cl}}=$ confidence interval; CYP17 = cytochrome P450c17; DASH = dynamic allele-specific hybridization; OR = odds ratio; $\mathrm{PCR}=$ polymerase chain reaction; RFLP = restriction fragment length polymorphism. 
In a population-based study about causes of postmenopausal breast cancer, which included 1,544 cases and 1,502 controls, we evaluated the association between CYP17 c.134T $>\mathrm{C}$ and breast cancer risk among Swedish women. We also explored potential interaction between genotype and menopausal hormone use and diabetes mellitus as well as age at menarche, age at menopause, age at first birth, parity and body mass index.

\section{Materials and methods Founding study}

This nation-wide case-control study included all Swedish women, 50 to 74 years of age and resident in Sweden between October 1993 and March 1995. During that period, all incident cases of primary invasive breast cancer were identified at diagnosis through the six regional cancer registries in Sweden, to which reporting of all malignant tumors is mandatory. Controls that matched the cases in 5-year age strata were randomly selected from the Swedish Registry of Total Population. Of the eligible cases and controls, 3,345 (84\%) and 3,454 (82\%), respectively, participated in the study by providing detailed information via questionnaires about menopausal hormone use, reproductive history, and other lifestyle factors. Results from the founding study have been published [24-28].

\section{Collection of biological samples}

Only postmenopausal women with a first primary breast cancer without any previous malignancy (except carcinoma in situ of the cervix or non-melanoma skin cancer) were eligible for the present study. Premenopausal women and those with a previous malignancy were excluded. From the eligible participants, we randomly selected 1,500 cases and 1,500 age-frequency (in 5-year groups) matched controls. We were interested in exploring the interaction between CYP17 c.1$34 \mathrm{~T}>\mathrm{C}$ and menopausal hormones and diabetes mellitus as both are breast cancer risk factors, possibly acting through increased levels of exogenous and endogenous estrogens, respectively. Thus, in order to increase statistical power in the subgroup analyses, we further selected all remaining eligible women (191 cases and 108 controls) that had used menopausal hormones (estrogen only or any combination of estrogen and progestin) for at least 4 years and all women (110 cases and 104 controls) with self-reported diabetes mellitus. In addition, 345 eligible controls from the founding study, originally selected for a parallel endometrial cancer study but who fulfilled the inclusion criteria to the breast cancer study, were added to our control sample. In total, we selected 1,801 cases and 2,057 controls.

Paraffin-embedded, non-cancerous tissue samples were collected for deceased breast cancer cases as well as for those breast cancer cases that declined to donate blood but consented to our use of the tissue. We obtained blood samples or archived tissue samples for 1,322 and 247 breast cancer patients, respectively, and blood samples from 1,524 controls. Population-based participation rates (taking into account those that did not participate in the founding study but could have been selected) for cases and controls were $73 \%$ and $61 \%$, respectively.

We isolated DNA from $3 \mathrm{ml}$ of whole blood using a Wizard Genomic DNA Purification Kit (Promega, Madison, WI, USA) according to the manufacturer's instructions. From non-malignant cells in paraffin-embedded tissue, we extracted DNA using a standard phenol/chloroform/isoamyl alcohol protocol [29]. The study was approved by the five Swedish Institutional Review Boards and was performed in compliance with the Helsinki Declaration.

\section{Genetic analyses}

We used two methods for CYP17 c.1-34T>C (rs743572) genotyping: Multiplex fluorescent solid-phase minisequencing [30]; and dynamic allele specific hybridization (DASH) [31]. Results from the two methods were validated with PCR-RFLP [32]. Twenty-four percent of the samples were analysed with both minisequencing and $\mathrm{DASH}$, and the genotypes obtained were identical. Primer and probe sequences and PCR reaction conditions are given in Additional file 1. The PCR reactions were performed on a Perkin Elmer GeneAmp 9700 system (PerkinElmer Life And Analytical Sciences, Inc., Boston, MA, USA).

\section{Statistical analyses}

Odds ratios (ORs) and 95\% confidence intervals (Cls) were calculated using conditional logistic regression models with the A1/A1 genotype as the reference group. We conditioned the models on age (due to matching) and on duration of menopausal hormone use and self-reported diabetes mellitus (due to our over-sampling scheme). The conditioning variables were thus age (5-year age groups), menopausal estrogen only use (never, $<4$ years or $\geq 4$ years), menopausal estrogen and progestin use (never, $<4$ years or $\geq 4$ years) and self-reported diabetes mellitus (yes or no). We chose to condition because in the presence of interaction between any of the selection variables and CYP17 genotype, estimates of the main effect of CYP17 could be biased. We did not expect confounding by other known breast cancer risk factors as they most likely would be intermediates between the genetic variant and breast cancer. We nevertheless included important breast cancer risk factors as co-variates in the models and assessed changes in the estimates of association between CYP17 genotype and breast cancer to investigate if there were any indications of such interrelations. Breast cancer risk factors other than menopausal hormone use that were analyzed for geneenvironment interaction were: Age at menarche ( $\leq 2$ years, $>12-14$ years or $>14$ years) and age at menopause $(<49$ years, 49-52 years or $>52$ years) (where $1^{\text {st }}$ category included the $1^{\text {st }}$ quartile of the data, $2^{\text {nd }}$ category the $2^{\text {nd }}$ and $3^{\text {rd }}$ quartiles, and $3^{\text {rd }}$ category the $4^{\text {th }}$ quartile); age at first birth 
Table 1

\begin{tabular}{|c|c|c|c|c|c|c|c|c|c|}
\hline & \multicolumn{2}{|c|}{ All genotypes } & \multicolumn{6}{|c|}{ CYP17 genotype } & \multirow{3}{*}{$\begin{array}{c}\mathrm{P} \text { for } \\
\text { interaction }\end{array}$} \\
\hline & \multirow[b]{2}{*}{$\begin{array}{l}\text { Cases/ } \\
\text { controls }^{\mathrm{a}}\end{array}$} & \multirow[b]{2}{*}{$\mathrm{OR}^{\mathrm{b}}(\mathrm{Cl})$} & \multicolumn{2}{|c|}{$\mathrm{A} 1 / \mathrm{A} 1$} & \multicolumn{2}{|c|}{$\mathrm{A} 1 / \mathrm{A} 2$} & \multicolumn{2}{|c|}{$\mathrm{A} 2 / \mathrm{A} 2$} & \\
\hline & & & $\begin{array}{l}\text { Cases/ } \\
\text { controls }\end{array}$ & $\mathrm{OR}^{\mathrm{b}}(\mathrm{Cl})$ & $\begin{array}{l}\text { Cases/ } \\
\text { controls }\end{array}$ & $\mathrm{OR}^{\mathrm{b}}(\mathrm{Cl})$ & $\begin{array}{l}\text { Cases/ } \\
\text { controlsa }\end{array}$ & $\mathrm{OR}^{\mathrm{b}}(\mathrm{Cl})$ & \\
\hline \multicolumn{10}{|c|}{ Age at menarche (years) } \\
\hline$\leq 12$ & $314 / 262$ & 1 (reference) & $102 / 96$ & 1 (reference) & $138 / 128$ & $1.1(0.7-1.5)$ & $74 / 38$ & $1.9(1.1-3.0)$ & \\
\hline$>12-14$ & $749 / 702$ & $0.9(0.7-1.1)$ & $283 / 251$ & $1.1(0.8-1.5)$ & $360 / 325$ & $1.1(0.8-1.5)$ & $106 / 126$ & $0.8(0.6-1.0)$ & \\
\hline$>14$ & $300 / 258$ & $1.0(0.8-1.2)$ & $107 / 94$ & $1.1(0.7-1.6)$ & $152 / 126$ & $1.2(0.8-1.7)$ & $41 / 38$ & $1.1(0.6-1.8)$ & 0.026 \\
\hline \multicolumn{10}{|c|}{ Age at menopause (years) } \\
\hline$<49$ & $330 / 347$ & 1 (reference) & $145 / 123$ & 1 (reference) & $141 / 165$ & $0.7(0.5-1.0)$ & $44 / 59$ & $0.7(0.4-1.1)$ & \\
\hline $49-52$ & $802 / 656$ & $1.3(1.1-1.6)$ & $282 / 243$ & $1.0(0.7-1.3)$ & $380 / 316$ & $1.0(0.8-1.4)$ & $140 / 97$ & $1.2(0.9-1.8)$ & \\
\hline$>52$ & $357 / 323$ & $1.2(1.0-1.5)$ & $119 / 117$ & $1.0(0.6-1.3)$ & $184 / 150$ & $1.1(0.8-1.6)$ & $54 / 56$ & $0.8(0.5-1.3)$ & 0.062 \\
\hline \multicolumn{10}{|c|}{ Age at first birth (years) } \\
\hline$\leq 24$ & $616 / 639$ & 1 (reference) & $225 / 236$ & 1 (reference) & $310 / 315$ & $1.1(0.8-1.3)$ & $81 / 88$ & $1.0(0.7-1.4)$ & \\
\hline $25-29$ & $414 / 388$ & $1.1(0.9-1.4)$ & $145 / 144$ & $1.1(0.8-1.5)$ & $187 / 171$ & $1.2(0.9-1.6)$ & $82 / 73$ & $1.2(0.8-1.7)$ & \\
\hline$\geq 30$ & $242 / 187$ & $1.4(1.1-1.7)$ & $100 / 67$ & $1.6(1.1-2.3)$ & $107 / 89$ & $1.3(0.9-1.8)$ & $35 / 31$ & $1.1(0.7-1.9)$ & 0.752 \\
\hline \multicolumn{10}{|l|}{ Parity } \\
\hline Nulliparous & $224 / 124$ & 1 (reference) & $79 / 41$ & 1 (reference) & $105 / 63$ & $0.9(0.5-1.5)$ & $40 / 20$ & $1.2(0.6-2.3)$ & \\
\hline 1 child & $320 / 240$ & $0.7(0.5-0.9)$ & $113 / 77$ & $0.8(0.5-1.2)$ & $168 / 130$ & $0.7(0.4-1.0)$ & $39 / 33$ & $0.6(0.3-1.1)$ & \\
\hline 2 children & $569 / 515$ & $0.6(0.4-0.7)$ & $215 / 195$ & $0.6(0.4-0.9)$ & $254 / 238$ & $0.5(0.4-0.8)$ & $100 / 82$ & $0.6(0.4-1.0)$ & \\
\hline$>2$ children & $386 / 459$ & $0.5(0.4-0.6)$ & $143 / 175$ & $0.4(0.3-0.7)$ & $184 / 207$ & $0.5(0.3-0.7)$ & $59 / 77$ & $0.4(0.2-0.6)$ & 0.792 \\
\hline \multicolumn{10}{|c|}{ Body mass index $\left(\mathrm{kg} / \mathrm{m}^{2}\right)$} \\
\hline$<25$ & $716 / 669$ & 1 (reference) & $263 / 230$ & 1 (reference) & $337 / 329$ & $0.9(0.7-1.2)$ & $116 / 110$ & $0.9(0.7-1.3)$ & \\
\hline 25 to $<28$ & $371 / 377$ & $1.0(0.8-1.1)$ & $141 / 137$ & $0.9(0.7-1.2)$ & $170 / 181$ & $0.9(0.7-1.2)$ & $60 / 59$ & $0.9(0.6-1.4)$ & \\
\hline$\geq 28$ & $403 / 278$ & $145 / 116$ & $1.2(0.9-1.6)$ & $198 / 121$ & $1.4(1.1-1.9)$ & $60 / 41$ & $1.4(0.9-2.2)$ & 0.657 & \\
\hline
\end{tabular}

alncluding only cases and controls with complete information on menopausal hormones and diabetes mellitus. ${ }^{b}$ Analyses were conditioned on age (5-year age groups), menopausal estrogen only use (never, $<4$ years or $\geq 4$ years), use of estrogen in combination with progestin (never, $<4$ years or $\geq 4$ years) and diabetes mellitus (yes or no). Cl, confidence interval; OR, odds ratio.

( $\leq 24$ years, $25-29$ years or $\geq 30$ years); parity (nulliparous, 1 child, 2 children or $>2$ children); and body mass index one year prior to diagnosis $(<25,25$ to $<28$, or $\geq 28)$. The last three were categorized according to cut-offs that in previous studies have been shown to be informative with regard to the variables' influence on breast cancer risk. The likelihood ratio test and the Wald test statistic were used to test for interaction. We performed all analyses using the SAS system (release 8.01; SAS Institute Inc., Cary, NC, USA).

\section{Results}

We obtained CYP17 c.1-34T>C genotypes from 1,544 breast cancer cases and 1,502 controls. Among the controls, genotype frequencies were similar to previously published frequencies in Caucasian populations [5,9-11,20,21] and did not deviate from Hardy-Weinberg Equilibrium ( $P=0.927)$. Geno- type frequencies among the cases did not differ between blood and tissue samples $(P=0.697)$.

We reproduced previously established breast cancer risk factor associations in this study population [24,25,33] (Table 1, first column). The one exception was age at menarche, which did not appear to be associated with overall breast cancer risk in this study [25].

The CYP17 c.1-34T>C was not associated with other breast cancer risk factors among the randomly selected controls (Table 2).

We found no overall association between CYP17 c.1-34T >C and breast cancer risk, regardless of histopathology (Table 3). This negative result was not modified by menopausal hormone use or diabetes mellitus (Table 3). We also did not detect any 
Table 2

Descriptive characteristics of postmenopausal breast cancer cases and controls by CYP17 c.1-34T>C genotype

\begin{tabular}{|c|c|c|c|c|c|c|c|c|c|}
\hline \multirow[b]{3}{*}{ Characteristic } & \multicolumn{9}{|c|}{ CYP17 genotype } \\
\hline & \multicolumn{3}{|c|}{$\mathrm{A} 1 / \mathrm{A} 1$} & \multicolumn{3}{|c|}{$\mathrm{A} 1 / \mathrm{A} 2$} & \multicolumn{3}{|c|}{$\mathrm{A} 2 / \mathrm{A} 2$} \\
\hline & $\begin{array}{l}\text { Cases/ } \\
\text { controls }^{\mathrm{a}}\end{array}$ & Cases & Controls & $\begin{array}{l}\text { Cases/ } \\
\text { controls }^{\mathrm{a}}\end{array}$ & Cases & Controls & $\begin{array}{l}\text { Cases/ } \\
\text { controls }^{\mathrm{a}}\end{array}$ & Cases & Controls \\
\hline Genotype frequencies & $550 / 488$ & 36.7 & 36.5 & $711 / 638$ & 47.4 & 47.7 & $238 / 212$ & 15.9 & 15.8 \\
\hline Age $\left(\right.$ years) ${ }^{b}$ & $550 / 488$ & $63.3 \pm 6.5$ & $63.0 \pm 6.5$ & $711 / 638$ & $63.4 \pm 6.5$ & $62.9 \pm 6.4$ & $238 / 212$ & $62.8 \pm 6.6$ & $63.2 \pm 6.1$ \\
\hline Age at menarche (years) ${ }^{\mathrm{b}}$ & $492 / 441$ & $13.5 \pm 1.4$ & $13.5 \pm 1.4$ & $650 / 579$ & $13.6 \pm 1.4$ & $13.5 \pm 1.4$ & $221 / 202$ & $13.2 \pm 1.5$ & $13.5 \pm 1.3$ \\
\hline Age at menopause (years) ${ }^{b}$ & $546 / 483$ & $49.9 \pm 3.8$ & $50.1 \pm 4.1$ & $705 / 631$ & $50.7 \pm 3.2$ & $50.0 \pm 3.8$ & $238 / 212$ & $50.6 \pm 3.2$ & $50.2 \pm 4.2$ \\
\hline Age at first birth (years) ${ }^{b}$ & $470 / 447$ & $25.4 \pm 5.0$ & $24.7 \pm 4.6$ & $604 / 575$ & $25.1 \pm 5.0$ & $24.7 \pm 4.7$ & $198 / 192$ & $25.6 \pm 4.5$ & $25.2 \pm 4.9$ \\
\hline Parity ${ }^{b}$ & $550 / 488$ & $1.9 \pm 1.2$ & $2.3 \pm 1.4$ & $711 / 638$ & $1.8 \pm 1.2$ & $2.1 \pm 1.2$ & $238 / 212$ & $1.8 \pm 1.2$ & $2.2 \pm 1.3$ \\
\hline Body mass index $\left(\mathrm{kg} / \mathrm{m}^{2}\right)^{\mathrm{b}}$ & $549 / 483$ & $25.8 \pm 4.1$ & $25.8 \pm 4.4$ & $705 / 631$ & $25.9 \pm 4.2$ & $25.2 \pm 3.8$ & $236 / 210$ & $25.7 \pm 4.4$ & $25.3 \pm 4.0$ \\
\hline \multicolumn{10}{|c|}{ Duration of menopausal hormone use (years) } \\
\hline 0 & $390 / 370$ & 70.9 & 75.8 & $469 / 473$ & 66.0 & 74.1 & $165 / 154$ & 69.3 & 72.6 \\
\hline$<4$ & $59 / 50$ & 10.7 & 10.3 & $96 / 74$ & 13.5 & 11.6 & $26 / 25$ & 10.9 & 11.8 \\
\hline$\geq 4^{d}$ & $101 / 68$ & 18.4 & 13.9 & $146 / 91$ & 20.5 & 14.3 & $47 / 33$ & 19.8 & 15.6 \\
\hline Self-reported diabetes mellitus ${ }^{c, d}$ & $550 / 488$ & 8.73 & 8.20 & $711 / 638$ & 9.42 & 7.21 & $238 / 212$ & 8.82 & 8.49 \\
\hline
\end{tabular}

alncluding only cases and controls with complete information on menopausal hormones and diabetes mellitus. bMeans \pm standard deviation.

cPercentages. dLong term users of menopausal hormones and women with diabetes mellitus were over-sampled.

association when we considered stage $1(n=389)$ and stage 2 or more advanced $(n=591)$ breast cancers separately (data not shown). None of these findings were altered by restricting the sample set to the randomly selected cases and controls or by including other breast cancer risk factors as co-variates in the logistic regression models.

In exploratory analyses, the A2/A2 genotype, compared to A1/ $A 1$, was associated with an increased breast cancer risk in women with age at menarche of 12 years or younger (OR 1.9, $95 \% \mathrm{Cl} 1.1-3.0$; $\mathrm{P}$ for interaction = 0.026; Table 1). Furthermore, the A2 allele in carriers conferred a decreased risk in women with menopause before 49 years of age; OR 0.7 (95\% Cl 0.5-1.0) for heterozygotes and OR 0.7 (95\% Cl 0.4-1.1) for homozygotes) compared to A1/A1. There was, however, no dose-response pattern in these findings and we therefore regarded them as being due to chance. Age at first birth, parity or body mass index did not seem to modify the non-association between CYP17 c.1-34T >C genotype and breast cancer risk (Table 1). All estimates remained unaffected after we restricted the analyses to the randomly selected cases and controls.

\section{Discussion}

CYP17 c. 1-34T $>C$ was not associated with breast cancer risk overall, a result that did not seem to be modified by menopausal hormone use or diabetes mellitus. Incidentally, we detected a statistically significant interaction between CYP17 c.1-
34T $>\mathrm{C}$ and age at menarche but regarded the finding as a chance result as no dose-response pattern was evident.

Our population-based study is one of the largest published to date, investigating the possible influence of CYP17 variation on breast cancer risk. Retrieval of extensive information on reproductive and lifestyle factors enabled us to test for geneenvironment interactions. Misclassification of genotypes should be minimal as is indicated by the identical results from replicate genotyping with two different methods, all blinded to case-control status. Any genotype misclassification despite these measures is unlikely to have been differential and would consequently only bias our estimates towards the null.

Because pre- and postmenopausal breast cancer is conceived to have differing causal mechanisms, these two types of cancer are often investigated separately. We were interested in potential interaction between CYP17 genotype and menopausal hormone treatment, which motivated our restricting the study population to postmenopausal women. Although it would be interesting to know also if CYP17 genotype influences the risk of premenopausal breast cancer, had we included both pre- and postmenopausal women, the study size would have had to be increased to have the same power to address our main hypotheses. We were also interested in exploring the interaction with diabetes mellitus as insulin resistance can lead to increased levels of plasma insulin, lower levels of plasma sex hormone binding globulin and, consequently, increased levels of free estrogen [34]. We thus over- 
Breast cancer risk in relation to CYP17 genotype, stratified by histopathological type, menopausal hormones or diabetes mellitus

\begin{tabular}{|c|c|c|c|c|c|c|c|}
\hline & \multicolumn{6}{|c|}{ CYP17 genotype } & \multirow{3}{*}{$\begin{array}{c}\mathrm{P} \text { for } \\
\text { interaction }\end{array}$} \\
\hline & \multicolumn{2}{|c|}{$\mathrm{A} 1 / \mathrm{A} 1$} & \multicolumn{2}{|c|}{$\mathrm{A} 1 / \mathrm{A} 2$} & \multicolumn{2}{|c|}{$\mathrm{A} 2 / \mathrm{A} 2$} & \\
\hline & Cases/controlsa & $\mathrm{OR}^{\mathrm{b}}(\mathrm{Cl})$ & Cases/controlsa & $\mathrm{OR}^{\mathrm{b}}(\mathrm{Cl})$ & Cases/controls ${ }^{a}$ & $\mathrm{OR}^{\mathrm{b}}(\mathrm{Cl})$ & \\
\hline All cancers & $550 / 488$ & 1 (reference) & $711 / 638$ & $1.0(0.9-1.2)$ & $238 / 212$ & $1.0(0.8-1.3)$ & \\
\hline Ductal cancers & $420 / 488$ & 1 (reference) & $510 / 638$ & $1.0(0.8-1.1)$ & $180 / 212$ & $1.0(0.8-1.3)$ & \\
\hline Lobular cancers & $56 / 488$ & 1 (reference) & $90 / 638$ & $1.3(0.9-1.8)$ & $24 / 212$ & $1.1(0.6-1.8)$ & \\
\hline \multicolumn{8}{|l|}{$\begin{array}{l}\text { Duration of } \\
\text { menopausal } \\
\text { hormone use(all } \\
\text { cancers) }\end{array}$} \\
\hline Never & $390 / 370$ & 1 (reference) & $469 / 473$ & $0.9(0.8-1.1)$ & $165 / 154$ & $1.0(0.8-1.3)$ & \\
\hline \multicolumn{8}{|l|}{ Any kind } \\
\hline$<4$ & $59 / 50$ & 1 (reference) & $96 / 74$ & $1.2(0.7-2.0)$ & $26 / 25$ & $1.0(0.5-2.1)$ & \\
\hline$\geq 4$ & $101 / 68$ & 1 (reference) & $146 / 91$ & $1.2(0.8-1.9)$ & $47 / 33$ & $1.0(0.6-1.7)$ & 0.668 \\
\hline \multicolumn{8}{|l|}{ Estrogen only } \\
\hline$<4$ & $28 / 22$ & 1 (reference) & $43 / 33$ & $1.1(0.5-2.3)$ & $7 / 11$ & $0.6(0.2-1.8)$ & \\
\hline$\geq 4$ & $39 / 23$ & 1 (reference) & $42 / 30$ & $1.0(0.5-2.1)$ & $15 / 13$ & $0.7(0.3-1.9)$ & 0.703 \\
\hline \multicolumn{8}{|c|}{ Estrogen + progestin } \\
\hline$<4$ & $42 / 41$ & 1 (reference) & $75 / 66$ & $1.2(0.7-2.1)$ & $23 / 21$ & $1.2(0.6-2.5)$ & \\
\hline$\geq 4$ & $64 / 47$ & 1 (reference) & $108 / 62$ & $1.3(0.8-2.2)$ & $34 / 20$ & $1.2(0.6-2.4)$ & 0.723 \\
\hline \multicolumn{8}{|c|}{$\begin{array}{l}\text { Self-reported diabetes } \\
\text { mellitus (all cancers) }\end{array}$} \\
\hline No & $502 / 448$ & 1 (reference) & $644 / 592$ & $1.0(0.8-1.2)$ & $217 / 194$ & $1.0(0.8-1.3)$ & \\
\hline Yes & $48 / 40$ & 1 (reference) & $67 / 46$ & $1.3(0.7-2.2)$ & $21 / 18$ & $1.1(0.5-2.3)$ & 0.259 \\
\hline
\end{tabular}

alncluding only cases and controls with complete information on menopausal hormones and diabetes mellitus. ${ }^{b}$ Analyses were conditioned on age (5-year age groups), menopausal estrogen only use (never, $<4$ years or $\geq 4$ years), use of estrogen in combination with progestin (never, $<4$ years or $\geq 4$ years) and diabetes mellitus (yes or no). $\mathrm{Cl}$, confidence interval; OR, odds ratio.

sampled menopausal hormone users and diabetics in the design phase of the study so as to increase statistical precision in subgroup analyses. We explored only the effect of CYP17 c. 1-34T >C on breast cancer risk in this article, but 13 variants in 7 genes were genotyped in the current phase of the study. Results from three of the studied genes in relation to breast cancer risk have previously been published [35-37].

The lack of association between CYP17 c.1-34T>C and overall breast cancer risk in our study is in line with results from 14 previous studies - where 10 included only Caucasian women - and a recent meta-analysis [5,9-22]. In contrast to Feigelson and colleagues [8], we did not find any association between this polymorphism and advanced breast cancer. Two groups have reported an association between CYP17 genotype and breast cancer risk in postmenopausal women [6,7]. All three studies were performed in non-Caucasian populations.
A possible mechanism for the CYP17 c.1-34T>C polymorphism to influence breast cancer risk is through increased biosynthesis of and, thereby, increased levels of circulating estrogen. Contrary to the predicted effect of the A2 allele, one group found decreased CYP17 mRNA levels in A2 carriers [38]. Studies regarding association of CYP17 c.1-34T $>C$ and circulating hormone levels as well as markers of hormonal status (i.e. age at menarche or menopausal hormone use) have recently been reviewed [39]. Increased estradiol levels have been associated with the A2 allele in premenopausal women $[6,32]$ as well as in postmenopausal women $[9,40]$, but three groups did not report any significant changes in hormone levels by genotype, two in postmenopausal women [17,41] and one in premenopausal women [42]. Results from seven studies have indicated a moderate association between the A2 allele and earlier menarche $[8,11,15,18,43-45]$, an association that was not detected in our study, nor in five others 
$[9,12,21,46,47]$. Furthermore, previous investigators have posited that CYP17 genotype may be associated with use of menopausal hormones, an important risk factor for breast cancer, but results have been inconsistent [11,12,21,48-50]. We found no such association in our data.

We identified an interaction with age at menarche, but considered it unlikely that the A2/A2 genotype would increase breast cancer risk in women with age at menarche less than 13 years without also moderately increasing risk in women with age at menarche between 12 and 14 years. Instead, the A2/A2 genotype decreased risk in the latter group, which is difficult to explain biologically. A similar pattern was seen for the interaction with age at menopause. To our knowledge, other groups have not reported comparable findings and we therefore believe the results to be caused by chance alone.

\section{Conclusion}

CYP17 c. 1-34T>C does not appear to have any major influence on breast cancer risk. Despite this negative finding, it would be prudent to investigate common variants covering the entire CYP17 gene before concluding that this gene has no role in breast cancer etiology.

\section{Competing interests}

The authors declare that they have no competing interests.

\section{Authors' contributions}

Kristjana Einarsdóttir wrote the article and performed the statistical analyses. Keith Humphreys and Gudrun Jonasdottir advised on the statistical methods. Tove Rylander-Rudqvist and Susanne Ahlberg performed the genetic analyses. Magnus Ingelman-Sundberg and Ingemar Persson conceived and designed the study. Elisabete Weiderpass oversaw the project progress and took part in interpretation and writing the article. Jianjun Liu and Kee Seng Chia critically revised the manuscript. Per Hall was involved in drafting the article, assisted in interpretation of data, and gave final approval of the version to be published. Sara Wedrén contributed to conception and design of the project, coordinated sample collection, was involved in writing the article, assisted in analysis and interpretation of data and gave final approval for publication. All authors read and approved the final manuscript.

\section{Additional files}

The following Additional files are available online:

\section{Additional File 1}

Microsoft Word document detailing the PCR reaction conditions as well as primer and probe sequences used to perform the minisequencing and DASH methods. See http://www.biomedcentral.com/content/ supplementary/bcr1319-S1.doc

\section{Acknowledgements}

We thank all the women who participated in the study and made it possible, especially those who took the effort to donate a blood sample. We are also grateful to Anthony S Gunnell for editing assistance and Fredrik Granath for statistical advice. This work was funded by the National Institute of Health, grant number R03 CA83114, the Swedish Cancer Society, grant number 4112-B99-02XBB, and the K\&A Wallenberg foundation (Wallenberg Consortium North, K Humphreys).

\section{References}

1. Bernstein L: Epidemiology of endocrine-related risk factors for breast cancer. J Mammary Gland Biol Neoplasia 2002, 7:3-15.

2. Nakajin S, Shinoda M, Haniu M, Shively JE, Hall PF: C21 steroid side chain cleavage enzyme from porcine adrenal microsomes. Purification and characterization of the 17 alphahydroxylase/C17,20-lyase cytochrome P-450. J Biol Chem 1984, 259:3971-3976.

3. Picado-Leonard J, Miller WL: Cloning and sequence of the human gene for $\mathrm{P} 450 \mathrm{c} 17$ (steroid 17 alpha-hydroxylase/17,20 lyase): similarity with the gene for P450c21. DNA 1987, 6:439-448.

4. Carey $\mathrm{AH}$, Waterworth $\mathrm{D}$, Patel $\mathrm{K}$, White $\mathrm{D}$, Little J, Novelli $\mathrm{P}$ Franks S, Williamson R: Polycystic ovaries and premature male pattern baldness are associated with one allele of the steroid metabolism gene CYP17. Hum Mol Genet 1994, 3:1873-1876.

5. Nedelcheva Kristensen V, Haraldsen EK, Anderson KB, Lonning $\mathrm{PE}$, Erikstein B, Karesen R, Gabrielsen OS, Borresen-Dale AL: CYP17 and breast cancer risk: the polymorphism in the 5 flanking area of the gene does not influence binding to Sp-1. Cancer Res 1999, 59:2825-2828.

6. Chacko P, Rajan B, Mathew BS, Joseph T, Pillai MR: CYP17 and SULT1A1 gene polymorphisms in Indian breast cancer. Breast Cancer 2004, 11:380-388.

7. Miyoshi Y, Iwao K, Ikeda N, Egawa C, Noguchi S: Genetic polymorphism in CYP17 and breast cancer risk in Japanese women. Eur J Cancer 2000, 36:2375-2379.

8. Feigelson HS, Coetzee GA, Kolonel LN, Ross RK, Henderson BE: A polymorphism in the CYP17 gene increases the risk of breast cancer. Cancer Res 1997, 57:1063-1065.

9. Haiman CA, Hankinson SE, Spiegelman D, Colditz GA, Willett WC, Speizer FE, Kelsey KT, Hunter DJ: The relationship between a polymorphism in CYP17 with plasma hormone levels and breast cancer. Cancer Res 1999, 59:1015-1020.

10. Mitrunen K, Jourenkova N, Kataja V, Eskelinen M, Kosma VM, Benhamou S, Vainio H, Uusitupa M, Hirvonen A: Steroid metabolism gene CYP17 polymorphism and the development of breast cancer. Cancer Epidemiol Biomarkers Prev 2000, 9:1343-1348.

11. Ambrosone $\mathrm{CB}$, Moysich $\mathrm{KB}$, Furberg $\mathrm{H}$, Freudenheim JL, Bowman ED, Ahmed S, Graham S, Vena JE, Shields PG: CYP17 genetic polymorphism, breast cancer, and breast cancer risk factors. Breast Cancer Res 2003, 5:R45-51.

12. Helzlsouer KJ, Huang HY, Strickland PT, Hoffman S, Alberg AJ, Comstock GW, Bell DA: Association between CYP17 polymorphisms and the development of breast cancer. Cancer Epidemiol Biomarkers Prev 1998, 7:945-949.

13. Huang CS, Chern HD, Chang KJ, Cheng CW, Hsu SM, Shen CY: Breast cancer risk associated with genotype polymorphism of the estrogen-metabolizing genes CYP17, CYP1A1, and COMT: a multigenic study on cancer susceptibility. Cancer Res 1999, 59:4870-4875.

14. Gudmundsdottir K, Thorlacius S, Jonasson JG, Sigfusson BF, Tryggvadottir L, Eyfjord JE: CYP17 promoter polymorphism and breast cancer risk in males and females in relation to BRCA2 status. Br J Cancer 2003, 88:933-936.

15. Weston A, Pan CF, Bleiweiss IJ, Ksieski HB, Roy N, Maloney N, Wolff MS: CYP17 genotype and breast cancer risk. Cancer Epidemiol Biomarkers Prev 1998, 7:941-944.

16. Hefler LA, Tempfer CB, Grimm C, Lebrecht A, Ulbrich E, Heinze G, Leodolter S, Schneeberger C, Mueller MW, Muendlein A, et al:: Estrogen-metabolizing gene polymorphisms in the assessment of breast carcinoma risk and fibroadenoma risk in Caucasian women. Cancer 2004, 101:264-269.

17. Dunning AM, Dowsett M, Healey CS, Tee L, Luben RN, Folkerd E, Novik KL, Kelemen L, Ogata S, Pharoah PD, et al:: Polymor- 
phisms associated with circulating sex hormone levels in postmenopausal women. J Natl Cancer Inst 2004, 96:936-945.

18. Wu AH, Seow A, Arakawa K, Van Den Berg D, Lee HP, Yu MC: HSD17B1 and CYP17 polymorphisms and breast cancer risk among Chinese women in Singapore. Int J Cancer 2003, 104:450-457.

19. Ahsan $\mathrm{H}$, Whittemore AS, Chen $\mathrm{Y}$, Senie RT, Hamilton SP, Wang Q, Gurvich I, Santella RM: Variants in estrogen-biosynthesis genes CYP17 and CYP19 and breast cancer risk: a familybased genetic association study. Breast Cancer Res 2005, 7:R71-81.

20. Verla-Tebit E, Wang-Gohrke S, Chang-Claude J: CYP17 5'-UTR MspA1 polymorphism and the risk of premenopausal breast cancer in a German population-based case-control study. Breast Cancer Res 2005, 7:R455-464.

21. Chang JH, Gertig DM, Chen X, Dite GS, Jenkins MA, Milne RL, Southey MC, McCredie MR, Giles GG, Chenevix-Trench G, et al.: CYP17 genetic polymorphism, breast cancer, and breast cancer risk factors: Australian Breast Cancer Family Study. Breast Cancer Res 2005, 7:R513-521.

22. Ye Z, Parry JM: The CYP17 MspA1 polymorphism and breast cancer risk: a meta-analysis. Mutagenesis 2002, 17:119-126.

23. Feigelson HS, McKean-Cowdin R, Henderson BE: Concerning the CYP17 MspA1 polymorphism and breast cancer risk: a meta-analysis. Mutagenesis 2002, 17:445-446. author reply 447-448

24. Magnusson C, Colditz G, Rosner B, Bergstrom R, Persson I: Association of family history and other risk factors with breast cancer risk (Sweden). Cancer Causes Control 1998, 9:259-267.

25. Magnusson CM, Persson IR, Baron JA, Ekbom A, Bergstrom R, Adami HO: The role of reproductive factors and use of oral contraceptives in the aetiology of breast cancer in women aged 50 to 74 years. Int J Cancer 1999, 80:231-236.

26. Magnusson C, Baron JA, Correia N, Bergstrom R, Adami HO, Persson I: Breast-cancer risk following long-term oestrogenand oestrogen-progestin-replacement therapy. Int J Cancer 1999, 81:339-344.

27. Moradi T, Nyren O, Zack M, Magnusson C, Persson I, Adami HO: Breast cancer risk and lifetime leisure-time and occupational physical activity (Sweden). Cancer Causes Control 2000, 11:523-531.

28. Terry $\mathrm{P}$, Wolk A, Persson I, Magnusson C: Brassica vegetables and breast cancer risk. JAMA 2001, 285:2975-2977.

29. Isola J, DeVries S, Chu L, Ghazvini S, Waldman F: Analysis of changes in DNA sequence copy number by comparative genomic hybridization in archival paraffin-embedded tumor samples. Am J Pathol 1994, 145:1301-1308.

30. Pastinen T, Partanen J, Syvanen AC: Multiplex, fluorescent, solid-phase minisequencing for efficient screening of DNA sequence variation. Clin Chem 1996, 42:1391-1397.

31. Prince JA, Feuk L, Howell WM, Jobs M, Emahazion T, Blennow K, Brookes AJ: Robust and accurate single nucleotide polymorphism genotyping by dynamic allele-specific hybridization (DASH): design criteria and assay validation. Genome Res 2001, 11:152-162.

32. Feigelson HS, Shames LS, Pike MC, Coetzee GA, Stanczyk FZ, Henderson BE: Cytochrome P450c17alpha gene (CYP17) polymorphism is associated with serum estrogen and progesterone concentrations. Cancer Res 1998, 58:585-587.

33. Magnusson C, Baron J, Persson I, Wolk A, Bergstrom R, Trichopoulos D, Adami HO: Body size in different periods of life and breast cancer risk in post-menopausal women. Int J Cancer 1998, 76:29-34.

34. Kaaks R: Nutrition, hormones, and breast cancer: is insulin the missing link? Cancer Causes Control 1996, 7:605-625.

35. Wedren S, Rudqvist TR, Granath F, Weiderpass E, Ingelman-Sundberg M, Persson I, Magnusson C: Catechol-O-methyltransferase gene polymorphism and post-menopausal breast cancer risk. Carcinogenesis 2003, 24:681-687.

36. Rylander-Rudqvist T, Wedren S, Granath F, Humphreys K, Ahlberg S, Weiderpass E, Oscarson M, Ingelman-Sundberg M, Persson I: Cytochrome P450 1B1 gene polymorphisms and postmenopausal breast cancer risk. Carcinogenesis 2003, 24:1533-1539.

37. Wedren S, Lovmar L, Humphreys $\mathrm{K}$, Magnusson $\mathrm{C}$, Melhus $\mathrm{H}$, Syvanen AC, Kindmark A, Landegren U, Fermer ML, Stiger F, et al.:
Oestrogen receptor alpha gene haplotype and postmenopausal breast cancer risk: a case control study. Breast Cancer Res 2004, 6:R437-449.

38. Daneshmand S, Weitsman SR, Navab A, Jakimiuk AJ, Magoffin DA: Overexpression of theca-cell messenger RNA in polycystic ovary syndrome does not correlate with polymorphisms in the cholesterol side-chain cleavage and 17alpha-hydroxylase/C(17-20) lyase promoters. Fertil Steril 2002, 77:274-280.

39. Sharp L, Cardy AH, Cotton SC, Little J: CYP17 gene polymorphisms: prevalence and associations with hormone levels and related factors. a HuGE review. Am J Epidemiol 2004 160:729-740.

40. Hong CC, Thompson HJ, Jiang C, Hammond GL, Tritchler D, Yaffe M, Boyd NF: Association between the T27C polymorphism in the cytochrome P450 c17alpha (CYP17) gene and risk factors for breast cancer. Breast Cancer Res Treat 2004, 88:217-230.

41. Tworoger SS, Chubak J, Aiello EJ, Ulrich CM, Atkinson C, Potter JD, Yasui Y, Stapleton PL, Lampe JW, Farin FM, et al:: Association of CYP17, CYP19, CYP1B1, and COMT polymorphisms with serum and urinary sex hormone concentrations in postmenopausal women. Cancer Epidemiol Biomarkers Prev 2004, 13:94-101.

42. Garcia-Closas M, Herbstman J, Schiffman M, Glass A, Dorgan JF: Relationship between serum hormone concentrations, reproductive history, alcohol consumption and genetic polymorphisms in pre-menopausal women. Int J Cancer 2002, 102:172-178.

43. Hamajima N, Iwata $\mathrm{H}$, Obata $\mathrm{Y}$, Matsuo $\mathrm{K}$, Mizutani M, Iwase $\mathrm{T}$, Miura S, Okuma K, Ohashi K, Tajima K: No association of the 5 promoter region polymorphism of CYP17 with breast cancer risk in Japan. Jpn J Cancer Res 2000, 91:880-885.

44. Gorai I, Tanaka K, Inada M, Morinaga H, Uchiyama Y, Kikuchi R, Chaki O, Hirahara F: Estrogen-metabolizing gene polymorphisms, but not estrogen receptor-alpha gene polymorphisms, are associated with the onset of menarche in healthy postmenopausal Japanese women. J Clin Endocrinol Metab 2003, 88:799-803.

45. Lai J, Vesprini D, Chu W, Jernstrom H, Narod SA: CYP gene polymorphisms and early menarche. Mol Genet Metab 2001, 74:449-457

46. Dunning AM, Healey CS, Pharoah PD, Foster NA, Lipscombe JM, Redman KL, Easton DF, Day NE, Ponder BA: No association between a polymorphism in the steroid metabolism gene CYP17 and risk of breast cancer. $\mathrm{Br} J$ Cancer 1998, 77:2045-2047.

47. Goodman MT, McDuffie K, Guo C, Terada K, Donlon TA: CYP17 genotype and ovarian cancer: a null case-control study. Cancer Epidemiol Biomarkers Prev 2001, 10:563-564.

48. Feigelson HS, McKean-Cowdin R, Pike MC, Coetzee GA, Kolonel LN, Nomura AM, Le Marchand L, Henderson BE: Cytochrome P450c17alpha gene (CYP17) polymorphism predicts use of hormone replacement therapy. Cancer Res 1999, 59:3908-3910.

49. Haiman CA, Hankinson SE, Colditz GA, Hunter DJ, De Vivo I: A polymorphism in CYP17 and endometrial cancer risk. Cancer Res 2001, 61:3955-3960.

50. McKean-Cowdin R, Feigelson HS, Pike MC, Coetzee GA, Kolonel $\mathrm{LN}$, Henderson BE: Risk of endometrial cancer and estrogen replacement therapy history by CYP17 genotype. Cancer Res 2001, 61:848-849. 